\title{
Levels of Readiness and Preparedness of Selected South African TVET Colleges in Meeting the Requirements of the Hospitality Industry
}

\author{
Mary Motolani Olowoyo*, Sam Ramaila and Lydia Mavuru \\ University of Johannesburg, South Africa \\ https://orcid.org/0000-0003-0332-8979 \\ https:/ / orcid.org/0000-0002-7351-477X \\ https://orcid.org/0000-0001-9099-0746
}

\begin{abstract}
Skill shortages within the hospitality sector is a major problem. The evaluation was undertaken to establish if the TVET colleges are well equipped to have a meaningful impact on the provision of appropriate skills required by the hospitality industry. The study adopted a mixed method approach as part of the survey design. The inherent structure of the curriculum was benchmarked against the expectations of employers of TVET college graduates. Data was collected through the administration of a survey questionnaire and semi-structured interviews. The survey questionnaire specifically examined available infrastructure at the TVET colleges utilised for hospitality studies, training provided by the academic personnel, curriculum content and employers' expected curriculum outcomes. Seven principals, 14 lecturers and 22 employers were interviewed using a semi-structured interview schedule. The key findings of the study revealed that the curriculum on offer placed considerable emphasis on Catering and Hotel Management. Entrepreneurship and Business Management courses are only offered at N5 level and Communication and Human Relations are offered at N6 level, notwithstanding the fact that they are largely regarded as core skills within the hospitality and tourism industry. Students are afforded work integrated learning opportunities on completion of their studies. Employers observed that a large proportion lacked skills. There appears to be sustained reluctance on the part of academic personnel and institutional management to harness funding. There is a critical need for coherent alignment between curriculum content and the needs of the hospitality industry through periodic reviews.
\end{abstract}

Keywords: TVET; hospitality industry; curriculum; skills' acquisition

\footnotetext{
*Corresponding author: Mary Motolani Olowoyo; Email: shyteeme@yahoo.co.uk
} 


\section{Introduction and Background}

The hospitality industry is reported to be the fastest growing sector in South Africa and across the world (Hospitality Outlook, 2015). The number of both local and foreign visitors patronising the industry has increased and it is estimated that the industry may get busier in the near future (Hospitality Outlook, 2015). South Africa is one of the top tourist destinations on the African continent, perhaps due to its long history of apartheid, rapid economic growth and development. The reports compiled by Modor Intelligence (2019) and the World Travel and Tourism Council (WTTC) (2019) showed that there were about 10.5 and 10.4 million foreign visitors in 2018 and 2017 respectively, while local travel recorded around 6 million visitors in 2018. The travel and tourism sector in the country accounts for $9.9 \%$ of total employment and is expected to increase to $11.5 \%$ by 2025 (WTTC, 2015). In order to accommodate the rising number of travellers and to satisfy their needs upon arrival in the country, the hospitality industry is expanding rapidly while still needing to score on dynamic key performance indicators, therefore requiring skilled personnel (Adukaite et al., 2016).

The hospitality sector as reported by Baum (2002) faces challenges in matching its skills requirements to the changing labour market. Skills shortages within the hospitality industry in South Africa is largely manifested in the form of workers' lower qualification levels (Global Human Capital Report, 2014). This pressing problem is not only peculiar to South Africa but appears to be a general trend across the globe. Baum (2002) further reported that the tourism and hospitality industry worldwide has been confronted with the problem of attracting and retaining quality employees resulting in a shortage of skilled personnel.

As reported in literature, within the hospitality industry, having a skilled, enthusiastic and committed workforce is seen as vital to the success of the industry (Kusluvan \& Kusluvan, 2000). This is important because most of the interactions between customers and clients are in the form of face-to-face exchanges, with the service being purchased and consumed at the same time. Hence, the standard of service provided is of paramount concern. Employee attitudes, performance and behaviour are key determinants of quality service as they have a direct linkage to customer satisfaction and loyalty. Reports have suggested low skills rates among employees of the hospitality industry (Green \& Masan, 2015). This has been compounded by the engagement of student trainees who are largely deployed to alleviate the problem of skills shortages afflicting the hospitality industry. However, student trainees were not particularly reliable and often took the work casually without understanding its full gravity (Wickham et al., 2008). At times, student employees tended to leave the organisation without notice (Alonso \& O'Neill's, 2009).

The purpose for the establishment of TVET colleges according to the DHET (2016) is to assist in producing graduates that are employable and work against the idea of just achieving improved levels of education without necessary skills. TVET colleges have been closely linked to the process of industrialisation and economic development and this imperative serves to position TVET colleges as institutions whose policies have often been dominated by economic and equity perspectives (UNESCO, 2012). South Africa has about 50 public Further 
Education and Training (FET) colleges (now referred to as TVET Colleges) which were created in 2002 in terms of the FET Act 98 of 1998. These colleges were established as a result of the merger of formal technical colleges, colleges of education and training centres.

Educational policy should empower the TVET colleges in assisting the graduates to acquire the necessary skills that will make them employable (McGrath, 2012). The hospitality industry is a labour intensive industry and is heavily reliant on availability of skilled labour to function effectively. It is only logical for both the government and the industry to seek ways to ensure a continuous supply of suitably skilled people for work. The Department of Education (2008) recommended that skills development programmes such as those in the hospitality sector be designed in a manner that addresses the needs of the sector, thus bridging the gap between the education system and the workplace. The department of education further recommended that within the hospitality sector, curriculum and skills development programmes be designed in a manner that addresses the needs of the sector, thus preparing graduates for immediate employment and make them attractive for the marketplace. Employers and role players within the hospitality industry are encouraged to play their role in attracting and retaining skills within the sector. A concerted effort among the stakeholders is called for where the employers may identify areas that need improvement and therefore determine the competencies required on the part of graduates before being employed (Kraak, 2004). It is envisaged that this undertaking will enable TVET college graduates to acquire qualifications based on required knowledge and skills. This assumption is based on the premise that TVET colleges play a pivotal role not only in providing education to the privileged few, but also assisting in strengthening the transition from school to the world of work through provision of additional opportunities in combating marginalisation that was experienced during the apartheid era (UNESCO, 2010).

In essence, there is a need to increase not only the numbers of TVET college graduates but also graduates with appropriate skills that meet the constantly changing demands of society and the economy. On completion of their studies, TVET college graduates are required to provide the necessary professional expertise needed to foster the development of the country. However, research has demonstrated that educational institutions are not keeping up with the provision of general skills needed by the $21^{\text {st }}$ century workforce (Mourshed et al., 2013). South African economy is characterised by high levels of unemployment and extreme job insecurity for many workers (Allais, 2012). There is a dearth in research that examines the provision of necessary skills required to meet the needs of the hospitality industry by TVET colleges in South Africa. The key issue being explored in the current study is whether TVET colleges are changing or adapting to new strategies in order to attract and train students as skilled personnel within the hospitality sector. This mission can be accomplished by investigating the extent to which TVET colleges are measuring up to their intended goals.

Curriculum assessment may be used as an effective tool in measuring the effectiveness and relevance of a course in society and this will assist in further evaluating student learning and preparedness (Kelly, 2004). The hospitality 
education is expected to place more emphasis on industry expectations and opinions. In essence, it has to provide a foundation that aids students in developing generic and transferable skills, work integrated learning to assist the students to acquire practical knowledge involved in operating a restaurant, and opportunities for students to learn in real life (Whitelaw et al., 2009). There is a need for relevant hospitality curriculum studies to focus not only on the theoretical aspects of the curriculum that involve the students but also on the employers' perspectives and expectations. Educators and students are therefore expected to assess the hospitality programmes rationally on how well they respond and contribute to students' readiness for their anticipated future hospitality careers and the methods used by the educators in developing the students and in curriculum development. Most TVET colleges are not responsive to the needs of society as educators are not well equipped to offer necessary information and assistance to the students. The colleges employ obsolete teaching methods underpinned by low quality infrastructure. This predicament stifles provision of appropriate training required to meet the needs of the hospitality sector in particular. The study therefore set out to investigate the curriculum content, skills acquisition, readiness, and preparedness of some selected TVET colleges in Pretoria and Johannesburg in relation to the needs of the labour market.

\section{Theoretical Framework}

The study is underpinned by a conceptual framework for leading curriculum change proposed by Terblanche (2017) as the underlying framework. The conceptual framework is predicated on three key pillars: contextualising TVET college curriculum, leading TVET curriculum change, and theoretical perspectives. The conceptual framework for leading curriculum change is illustrated in Figure 1 below.

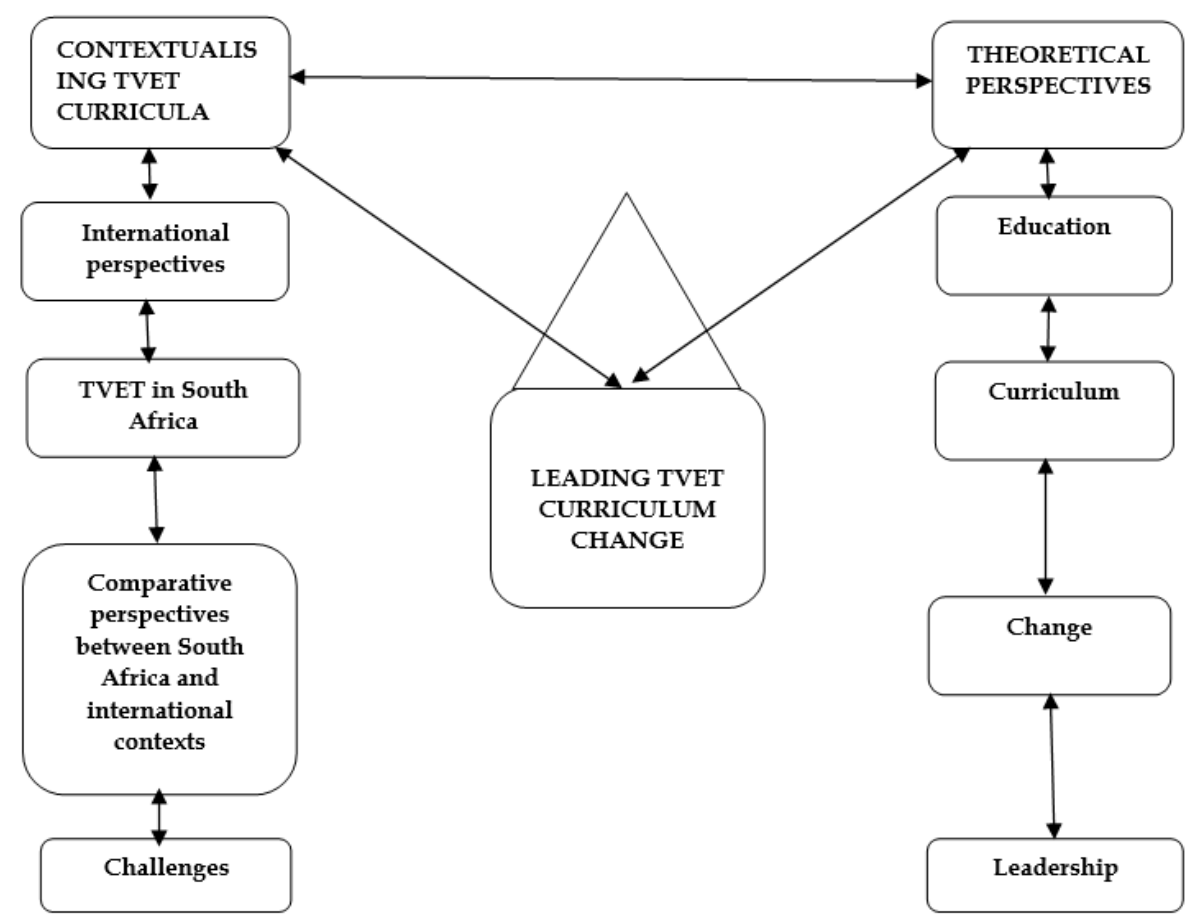

Figure 1: A conceptual framework for leading curriculum change (Terblanche, 2017) 
The framework clearly portrays the factors that can be considered in improving the TVET college curriculum in response to not only the needs of the industry, but also benchmarking the standards against the international markets. This is pertinent as the hospitality sector is a very competitive industry and is an important source of wealth generation for the nation.

\subsection{Purpose of the study}

The study investigated some of the challenges associated with the implementation of hospitality curriculum in selected TVET Colleges in South Africa. The empirical investigation was guided by the following research question:

What are the levels of readiness and preparedness of selected South African TVET colleges in meeting the requirements of the hospitality industry?

To answer the main research question, the following sub-questions were formulated.

- To what extent does the hospitality curriculum offered by TVET colleges in South Africa foster skills acquisition?

- What is the level of readiness and preparedness of selected TVET colleges for provision of appropriate skills and competencies required by the hospitality sector within the South African context?

- What alignment exists, if any, between the hospitality training provided by TVET colleges and the needs of the hospitality sector?

\section{Research Design and Methodology}

Both qualitative and quantitative methods was used in this study but the qualitative aspect was dominant in order to get a deeper and more genuine expression of beliefs and values that emerged during the conversations. The quantitative aspect was used for the TVET college principals in form of semi structured questionnaires because of the nature of their work.

A mixed method approach was used for the study as part of a survey design. According to Brannen (2007), mixed method research may be a mix of qualitative and quantitative methods, a mix of quantitative methods, or a mix of qualitative methods. This study adopted a mix of quantitative and qualitative methods and combined or integrated quantitative and qualitative research methods as components of a research (Creswell, 2013). This was deemed important in order to add value to the research by increasing the validity of the findings and assisting with knowledge creation (McKim, 2017). The other noteworthy aspect of mixed method research is the integration of various components which gives readers more confidence in the results and the conclusion thereof which can lead to a future research (O'Cathain et al., 2010). The qualitative aspect of the research was dominant in the sense that more emphasis was placed on the understanding of the contextual factors influencing the implementation of the curriculum by TVET colleges with regards to skills acquisition by students (Creswell \& Plano, 2009). The qualitative aspect of the research provided a critical understanding of specific contextual factors 
influencing skills development by TVET colleges, the impact of curriculum content, and labour market expectations.

\subsection{Sampling}

The study involved purposively selected seven TVET colleges located in Pretoria (three) and Johannesburg (four) as the two major cities in the Gauteng Province of South Africa. Purposive sampling was used in order to identify and select individuals that could provide adequate useful information (Patton, 2002). The selection involved careful identification of participants (principals, teachers and hospitality managers) that were knowledgeable about the hospitality industry (Creswell \& Plano, 2011). The participants were selected on the basis of their availability, willingness to participate, and their ability to communicate their experiences and opinions.

\subsection{Research context}

The selected TVET colleges are located in Pretoria and Johannesburg as the two major cities in the Gauteng Province of South Africa. Pretoria is South Africa's administrative capital. The city of Pretoria is also the traditional centre of government and commerce. Many banks, businesses, large corporations, shops, shopping centres, and other businesses are situated in the city centre boasting several large skyscrapers. Johannesburg, on the other hand, is a transit point for connecting flights to Cape Town, Durban, and the Kruger National Park. As the economic hub of South Africa, Johannesburg provides shopping opportunities for tourists and offers a range of venues and experiences, from numerous upmarket shopping malls such as Sandton City and Nelson Mandela Square, to various markets and flea markets, such as the Oriental Plaza and the Rosebank Flea Market.

\subsection{Data collection}

Before data collection the structure and content of the TVET college curriculum was benchmarked against the expectations of employers of TVET college graduates using literature from previous studies. The information was used in designing a survey questionnaire which sought to establish how well prepared TVET colleges were in providing appropriate skills required by the hospitality industry. The questionnaire was designed to obtain information both from TVET colleges and employers. The information sought included admission criteria, pass rate, enrolment rate for the course, availability of educators and educators' qualifications, available infrastructure, laboratory space, course content (N2, N3 and N4), training opportunities such as conferences and workshops for lecturers, training opportunities provided by employers, and assessment practices adopted to evaluate the competence and skills acquired by the trainees. The questionnaire was then piloted to a few TVET hospitality lecturers who did not form part of the participants for the study to check its readability and for issues that could be improved. The revised survey questionnaire was then administered to the participants (lecturers and employers) to explore: 1) The effectiveness of the hospitality education studies curriculum; 2) level of readiness and preparedness of selected TVET colleges for provision of appropriate skills and competencies; and 3) the alignment between the technical training provided by TVET colleges and the needs of the hospitality industry. The survey questionnaire was designed to obtain information on the key issues 
under investigation in the study and was sent to the principals of each school and employers from different hospitality industries (hotel, tourist companies and restaurants). Quantitative data was collected to quantify the problem by way of generating numerical data that could be transformed into usable statistics.

After analysis of data from questionnaires, seven principals, 14 lecturers and 22 employers were interviewed using a semi-structured interview schedule. Qualitative data obtained provided elaboration on trends emerging from quantitative data. According to Creswell (2003), a qualitative interview occurs when a researcher asks one question or more from a participant at a time. The interviews conducted provided a clear understanding of the situation in the colleges and a basis for interpretation. Participants expressed themselves freely as they were interviewed in their natural settings. The questionnaire was piloted to a few TVET hospitality lecturers who did not form part of the participants for the study to check its readability and issues that could be improved. The revised survey questionnaire was then administered to the participants (lecturers and employers) to explore: 1) the effectiveness of the hospitality education studies curriculum; 2) level of readiness and preparedness of selected TVET colleges for provision of appropriate skills and competencies; and 3) the alignment between the technical training provided by TVET colleges and the needs of the hospitality industry.

\subsection{Data analysis}

The qualitative data was presented in the form of report writing. Data analysis is the systematic organisation and synthesis of research data, and the testing of a research hypothesis using that data (Polit \& Hungler, 1999). SPSS Version 23.0 was used to analyse quantitative data and descriptive and inferential statistics were obtained. Descriptive statistics enabled the researchers to reduce, summarise, and describe quantitative data obtained from empirical evidence (Polit \& Beck, 2004). Qualitative data was analysed using the descriptive method in terms of the narrative information gathered during the interview to interpret the results (Creswell, 2003).

Before data collection, the structure and content of the TVET college curriculum was benchmarked against the expectations of employers of TVET college graduates using literature from previous studies. The information was used in designing a survey questionnaire which sought to establish how well prepared TVET colleges were in providing appropriate skills required by the hospitality industry. The questionnaire was designed to obtain information both from TVET colleges and employers.

\subsection{Validity and reliability}

Validity was achieved through representativeness of the sample and by ensuring that questions asked served the intended purpose. Reliability was achieved by ensuring that questions elicited the same type of information each time they were used under the same conditions. The questionnaire was piloted and information obtained was used to revise the items. In respect of qualitative data, the following validity and reliability checks proposed by Merriam (1998) were adhered to: 
- Triangulation: Claims and tentative interpretations were triangulated through multiple meetings that were held with the participants during the research process and the use of multiple and different data collection methods.

- Member checks: Data collected and tentative interpretations were discussed during reflection sessions and were confirmed by the participants.

- Peer review: There was ongoing dialogue and critical reflection with other researchers on the research process and tentative interpretations.

- Reflexivity: The researchers engaged in critical self-reflection regarding anything that may have biased the interpretation of data e.g. hidden assumptions, own worldview, theoretical orientation, and interrelationships. Biases and assumptions were made explicit.

- Audit trails: A detailed account of methods, procedures, and reasons for decisions taken was compiled.

- Rich description: A detailed description of events characterising the research process was provided to contextualise the study and to judge the extent to which the findings applied to the research situation.

\section{Results and Discussion}

The quantitative aspect was nested in the qualitative and intended to determine the TVET college responses to the study under investigation. Hence, the data was presented in a report form because the study relied most heavily on qualitative data but supplemented it with quantitative survey results.

The key findings emanating from the study are clustered according to two broad categories, namely: (a) scope, curriculum, and general assessment of TVET colleges offering hospitality studies, (b) employers' experiences of TVET hospitality graduates.

\section{SCOPE, CURRICULUM, AND GENERAL ASSESSMENT OF TVET COLLEGES OFFERING HOSPITALITY STUDIES}

A reflection on the key areas investigated under this category is provided below. Related findings from questionnaires and interviews are presented together.

\section{Admission Policy}

The admission policy of students into TVET colleges did not specify a particular symbol or grade in any subject for admission into the hospitality programme. The lecturers indicated that just a matric pass is required to gain admission and that preference is usually given to students with Grade 12 Home Economics /Hospitality studies or other relevant subjects. Other relevant subjects include English Language and any subjects passed at matric level. The lecturers strongly argued in favour of a review of the admission policy. The introduction of a welldesigned and modest mode of admission will not only reduce the unsuccessful degree completion rate but bring about effective output on the part of graduates (Declercq \& Verboven, 2018). The key determinants of a students' admission to colleges and universities remain controversial as in some instances, high school performance may not necessarily represent students' true academic potential (Hoare \& Johnson, 2010). A study conducted by Cyrenne and Chan (2012) showed that high school scores and pass rates are a strong predictor of good 
university performance although other factors such as finance and family background also play a significant role. The lecturers further mentioned that a pass symbol in English Language at matric level is perceived to be sufficient because students require basic communication skills. The lecturers were particularly concerned about the high dropout rate due to students' inability to cope with the cognitive demands of their studies caused by their weak educational background as reflected in their National Senior Certificate results. This sentiment is captured in the following response of one of the lecturers.

The hospitality industry does not centre on cooking only where you are expected to stay in the kitchen, but you may be asked to work at the front desk, so you need good communication skills, hence good symbols from the high school especially in English will be ok.

\section{Course Structure}

The course structure placed considerable emphasis on Catering and Applied Management. Courses such as Entrepreneurship and Business Management which allow students to use their entrepreneurial skills and advance as fast as possible by utilising innovative ideas despite having very few resources, are only introduced at N5 level. Communication and Human Relations are only introduced at N6 level. Unfortunately, work integrated learning opportunities are only provided after the completion of N6. This practice is viewed as a structural weakness as work integrated learning ought to form an integral part of hospitality training before graduation. By its very nature, work integrated learning should provide the necessary practical training required to navigate the complex work related demands associated with the hospitality industry. The lecturers also indicated that students were given logbooks to monitor their daily activities during the course of the training.

The curriculum adopts a vocational approach which may not necessarily equip the students with the requisite skills to perform managerial duties and this is similar to the initial approach adopted in the United Kingdom which was later changed as a result of its perceived inherent restrictive limitations placed upon the graduates (Alexander et al., 2009). Hospitality curriculum should move away from the exclusive traditional focus on practical skills to a comprehensive approach providing a good balance in terms of practical skills in leadership, commerce, and other transferable skills (Alexander et al., 2009; Farbrother \& Dutton, 2005). This fundamental paradigm shift would serve to strengthen the hospitality curriculum on offer thereby addressing the mismatch between the hospitality training provided by TVET colleges and needs of the hospitality industry. Smith and Cooper (2000) suggested that hospitality curricula should involve industry operation knowledge-related courses and general managerial competencies-related courses.

\section{Lecturers' Qualifications}

Most of the lecturers held a Diploma, Bachelor of Education degree or Bachelor of Education Honours degree. A smaller proportion of the staff complement held a master's degree. Three of the lecturers indicated that they were pursuing master's degree studies. On a positive note, the lecturers held a teaching qualification which appeared to be a reasonable reflection of their pedagogical 
competence as instructors. TVET college lecturers in South Africa have numerous skills development challenges (Coetzee et al., 2011). Verster (2011) identified professional inadequacies among the TVET lecturers ranging from inexperience, lack of vocational competency, lack of qualifications, and lack of professionalism. Similarly, the lecturers in the current study showed limited knowledge and skills, and had a lack of quality infrastructure to fully equip their students with the necessary skills. These professional inadequacies render the curriculum review process a daunting task. The Government Gazette Policy on Professional Qualifications (2013) for TVET Lecturers puts particular emphasis on three key areas: pedagogy, didactics, and workplace experience. The emphasis on envisaged key areas is viewed as a viable means through which curriculum outcomes can be realised.

\section{Laboratory Equipment}

The lecturers bemoaned the lack of modern equipment required for the provision of hospitality training. Optimal utilisation of the capital budget is largely hampered by bureaucratic practices within TVET colleges. This is an operational inefficiency which ought to be addressed to ensure optimal utilisation of the allocated capital budget. This sentiment is reflected in the following excerpt from one of the participants.

Yes, the government is providing adequate funding for the TVET colleges but you will need to fill and fill so many forms until you can get the money out. Remember you still have classes to teach, test and exams to mark, so it is better if you can see what to do and manage what you have.

The response shows that the participant finds the whole process of acquiring resources tiring and taxing, which means at times they may prefer to forego the application for funding process and resort to using the limited resources. In order to circumvent the lack of essential resources, lecturers are compelled to deploy improvised resources. The following excerpt underscores the need for improvisation.

I bring most of the things I use for practical from home, but you have to know it is just a little quantity, just for the student to see and understand how it is done. It is just for them to see but when they get to their workplace or during internship they will see everything.

This means that the quality of the laboratory equipment utilised for training is not commensurate with the envisaged curriculum outcomes. A comprehensive audit of available infrastructure at TVET colleges ought to be undertaken with a view to adequately addressing infrastructural deficiencies. The following excerpt attests to these fundamental concerns.

Our equipment is there to mimic the situation within the main industry, this will just provide basic information on how to do it. We cannot be expected to have most of the equipment used in the industry here at the school. This is not for a business purpose and we are not competing for customers, our main objective is to provide learners with the opportunity to learn the method and see how it works. During the 
industrial training at the end of their course, they will see and will be taught on how to use other equipment.

Fundamental concerns expressed in this regard do not auger well for the provision of quality hospitality training. The participants emphasised the need to do justice to hospitality training as a meaningful response to the needs of the hospitality sector as reflected in the following excerpt. The participants, mainly the employers, were dissatisfied with the level of training that students receive from the TVET colleges as attested by one participant who said, "Hospitality training is not just about cooking or hotel work it goes beyond that, it may involve working at the front desk, welcoming guest among others".

Lack of adequate infrastructure can lead to widespread dissatisfaction with the TVET college graduates (Pitan \& Adedeji, 2012; McCowan, 2017). There is a need to align the training provided with the strategic mandate of TVET colleges. In terms of the strategic mandate, TVET colleges have been established to serve as an integral part of general education, a means for preparing students for occupational fields and effective participation in the world of work, an aspect of lifelong learning and preparation for responsible citizenship, an instrument for promoting environmentally sound, sustainable development, and a method of alleviating poverty.

\section{Curriculum review and evaluation}

The review of the curriculum is the key prerogative of the Department of Higher Education and Training (DHET). The DHET is supposed to provide guidelines on what is necessary for inclusion in the curriculum. The lecturers expressed discontent about lack of consultation on curriculum review as captured in the following excerpt.

The government through the DHET usually conduct research into the quality and relevance of the curriculum; this should be carried out every five years.

When asked whether the curriculum aligns to the needs of the industry, the participants indicated that the curriculum is structured in such a way that it provides basic and background information on hospitality studies. The structural deficiency of the curriculum is encapsulated in the following excerpt.

The hospitality study is not about the theoretical aspect of the work as detailed in the curriculum, but also practical oriented and aligned towards the needs of the industries.

Other lecturers were not keen to be involved in curriculum review as it was viewed as an arduous undertaking which requires specialist expertise. To show that lecturers are conflicted when it comes to going the extra mile in developing the students more fully, they indicated that monitoring the quality of work and integrating that into learning is an extremely difficult and complex undertaking. As such, students are afforded such opportunities on completion of their studies. The following excerpt captures this sentiment.

It will be difficult to do a follow up because some of the students go back to their provinces looking for placements for internships, who will pay 
us for a follow up and where is the time? We only check their logbooks at the completion of their training.

There is a need to adopt an authentic turnaround strategy that can be implemented to carry out a complete overhaul of the TVET sector. TVET colleges have an overarching strategic mandate which is geared towards the fulfilment of economic and societal needs through meaningful enhancement of human capital development. The reconfiguration of the TVET sector should address structural deficiencies that serve to hinder provision of appropriate hospitality training in general. More specifically, work integrated learning is largely viewed as a pathway to enhancing employability of students after the completion of their courses (Chen et al., 2018; Binder et al., 2015; Yiu \& Law, 2012; Zopiatis \& Constanti, 2012). The significance of the provision of appropriate training through utilisation of state of the art infrastructure cannot be over-emphasised.

\section{EMPLOYERS' EXPERIENCES OF TVET HOSPITALITY GRADUATES}

A reflection on the key areas investigated under this category is provided below.

\section{General view of employers}

The managers interviewed indicated that most of the TVET graduates are usually employed as entry level employees due to their limited practical experience and lack of adequate work exposure. This sentiment is encapsulated in the following excerpt.

Even those that want to work as chefs find it difficult to cope at the very first few months because they've never been exposed to such working condition and you just have to train them again and again.

Employers have expressed reservations about TVET college graduates' lack of generic and specialist skills. Breytenbach (2010) posits that the hospitality curriculum should make provision for the development of skills, key professional attributes and competencies required by different components of the hospitality industry as it offers graduates a broad range of employment opportunities.

\section{Communication skills}

Managers bemoaned the quality of communication skills demonstrated by newly qualified TVET college graduates. This is unfortunate because communication skills are crucially significant and required for the navigation of work related challenges associated with the hospitality industry. Additional important skills identified by employers include interpersonal skills, problem solving skills, and self-management skills (Lee \& Lee, 2012). Lolli (2013) asserted that a curriculum that does not focus mainly on written skills and formal presentation, but also interpersonal skills that will assist in improving communication skills of TVET college graduates. The following excerpt attests to these sentiments.

This is an important aspect of our business, but it is always difficult to put fresh TVET graduates in this section, they find it difficult to speak fluently with the customer, maybe because they were new in the 
business or they were timid, I don't know. Yeah, it is very important that you speak good English, though some clients prefer other languages, if you cannot speak fluently, how then will you be able to convey the message clearly?

TVET college graduates operate in multilingual environments. This reality underscores the need for the hospitality curriculum to provide opportunities to embrace language diversity as the following excerpt demonstrates.

Just imagine you understand Chinese language, so many of the employers will be willing to have you because this will go a long way in welcoming the visitors. If you know other languages outside South African languages, you are just going to get a job like that within the hospitality industry, say for example you can speak French or Chinese, you will be needed at the airport.

The hospitality industry is a rapidly growing and competitive industry. Hence the need for managers and employees to have adequate problem solving skills and analytical skills required for sustainable administration of the hospitality industry (Adeyinka-Ojo \& Khoo-Lattimore, 2013; Adeyinka-Ojo, 2018).

\section{Use of industrial equipment by TVET college graduates}

Industrial machines are used in order to facilitate quick, efficient, and effective services. However, TVET college graduates' skill set usually reflect knowledge gaps particularly when it comes to effective utilisation of relevant equipment. This deficiency points to the need to strengthen the hospitality curriculum with a view to ensure provision of holistic training. In this regard, Kamau and Waduo (2012) contend that low quality skills acquired by TVET college graduates reflect the quality of the training provided by the academic personnel. These sentiments are reflected in the following excerpt.

When they come here, they only know the basic things; you have to teach them right from the onset, the skills are not there. However, if you train, them they tend to do more because they are placed on salaries per month not on the hourly basis like the waiters.

\section{Time allocated for practical training}

The majority of managers recommended that more time should be dedicated to practical training. The practical training should involve practical scenarios capturing operational challenges associated with the hospitality sector.

\section{Interpretation of key findings in terms of the adopted conceptual framework}

The study is underpinned by a conceptual framework for leading curriculum change proposed by Terblanche (2017). The conceptual framework is predicated on three key pillars: contextualising TVET college curriculum, leading TVET curriculum change, and theoretical perspectives. There is a crucial need to contextualise the hospitality curriculum offered by TVET colleges in South Africa to ensure alignment between the nature of the training provided and the needs of the hospitality sector. Comprehensive reconfiguration of the hospitality curriculum to address inherent structural weaknesses ought to be informed by international perspectives in order to fully embrace international best practices. 
As a member of the global community of nations, South Africa faces the imperative to provide a globally competitive hospitality curriculum in order to develop capacity to harness global opportunities. Fundamental challenges associated with the implementation of the hospitality curriculum are not confined to South Africa. For instance, the United Kingdom is grappling with similar challenges.

The process of leading TVET curriculum change is an extremely difficult and complex undertaking. This undertaking requires the provision of strategic and visionary leadership. Building leadership capacity at TVET colleges remains a key strategic imperative. Meaningful skills development can only be realised through provision of quality education. Provision of quality education requires the deployment of appropriately qualified academic personnel, yet the qualification levels of the academic personnel providing training at TVET colleges in South Africa are not satisfactory. This has been identified as one of the key contextual factors stifling the provision of appropriate hospitality training. Comprehensive reconfiguration of the hospitality curriculum should bring about transformative change that is geared towards meaningful enhancement of human capital development in its broadest sense. The hospitality sector contributes substantially to South Africa's gross domestic product. The provision of skills required for sustainable development of the hospitality sector must be carefully reconsidered to ensure optimal economic growth that is needed to accelerate socioeconomic development within the broader South African context.

\section{Recommendations arising from the study}

The following contextually appropriate recommendations are proposed for strengthening the implementation of the hospitality curriculum.

- There is a critical need to establish alignment between the hospitality curriculum offered by TVET colleges and the needs of the hospitality sector with a view to ensure gainful employment of graduates on completion of their training.

- The hospitality curriculum ought to put considerable emphasis on the provision of holistic training of graduates.

- Work integrated learning should be a compulsory characteristic feature of the hospitality curriculum.

- The hospitality curriculum should be reviewed on an ongoing basis to keep pace with rapid development associated with the advent of the Fourth Industrial Revolution.

\section{Conclusion}

The hospitality curriculum offered by TVET colleges produces graduates with pervasive knowledge gaps. There is a critical need for a comprehensive overhaul of the hospitality curriculum to ensure that it contributes to meaningful enhancement of human capital development. The academic personnel ought to be afforded opportunities to improve their qualifications through accelerated professional development programmes to safeguard the quality of the training provided by TVET colleges. 
The findings show that the selected TVET colleges tend to fall short when it comes to their readiness and preparedness in providing students with the appropriate skills and competencies required by the hospitality sector within the South African context. The structure and some of the content seems limiting and is mainly focused on technical skills. Therefore, there may be a need to review the curriculum every five years.

\section{Limitation of the study}

No research is absolute, therefore, the current study had some limitations. The study centred on a particular province, therefore the findings of the study should be considered along with its limitations as this may not be the case with other provinces in South Africa. Another limitation is the fact that not much work has been done on curriculum review for hospitality studies at TVET colleges, hence, the researchers could only use the available journals.

\section{Suggestion for further Research}

Like any other service, the quality of hospitality studies is reliant on the quality of the curriculum. Further studies should seek to investigate the extent to which the qualifications of TVET lecturers prepare the students for future sustainable work.

\section{References}

Adukaite, A., Van Zyl, I., \& Cantoni, L. (2016). The role of digital technology in tourism education: A case study of South African secondary school. Journal of Hospitality, Leisure and $\mathcal{E}$ Tourism Education, 19, 54-65. https://doi.org/10.1016/j.jhlste.2016.08.003

Adeyinka-Ojo, S. F. (2018). A strategic framework for analysing employability skills deficits in rural hospitality and tourism destinations. Tourism Management Perspectives, 27, 47-54. https://doi.org/10.1016/j.tmp.2018.04.005

Adeyinka-Ojo, S. F., \& Khoo-Lattimore, C. (2013). Slow food events as a high yield strategy for rural tourism destinations: The case of Bario, Sarawak. Worldwide Hospitality and Tourism Themes, 5(4). https://doi.org/10.1108/whatt-03-20130012

Allais, S. (2012). Will skills save us? Rethinking the relationships between vocational education, skills development policies, and social policy in South Africa. International Journal for Educational Development, 32(5), 632-642. https://doi.org/10.1016/j.ijedudev.2012.01.001

Alexander, M., Lynch, P., \& Murray., R. (2009). Reassessing the core of hospitality management education and the continuing importance of training restaurant. Journal of Hospitality, Leisure, Sport and Tourism Education, 8, 55-69. https:// doi.org/10.3794/johlste.81.203

Alonso, A., D., \& O 'Neil., M. (2009). Exploring consumers' images of open restaurant kitchen design. Journal of Retail and Leisure Property, 9, 247-259. https:// doi.org/10.1057/rlp.2010.5

Binder, J. F., Baguley, T., Crook, C., \& Miller, F. (2015). The academic value of internships: Benefits across disciplines and student backgrounds. Contemporary Educational Psychology, 41, 73-82. https:// doi.org/10.1016/j.cedpsych.2014.12.001

Brannen, J. (2007). Mixing methods: The entry of qualitative and quantitative approaches into the research process. International Journal of Social Research Methodology, 8(3). https://doi.org/10.1080/13645570500154642 
Breytenbach, A. (2010). An evaluation of tourism industry perceptions of tourism programmes of selected further and higher education institutions in the Western Cape. Thesis and dissertations, CPUT. Paper $149 . \quad$ Retrieved from http://dk.cput.ac.za/td_cput/149

Chen, T. L., Shen, C., \& Gosling, M. (2018). Does employability increase with internship satisfaction? Enhanced employability and internship satisfaction in a hospitality programme. Journal of Hospitality, Leisure, Sport and Tourism Education, 22, 88-99. https://doi.org/10.1016/j.jhlste.2018.04.001

Coetzee, D., Green, W., McBride, T., Singh, A., \& Verster, J. (2011). Presentation on the current FET lecturer profile. Workshop on continuing professional development for FET lecturers. SACPO. Retrieved from https://www.ecsecc.org/documentrepository/informationcentre/fetskillsaudit _27421.pdf

Creswell, J. W. (2003). Research design qualitative, quantitative. and mixed methods approaches (2nd ed.). Sage Publication. Retrieved from http://fe.unj.ac.id/wpcontent/uploads/2019/08/Research-Design_Qualitative-Quantitative-andMixed-Methods-Approaches.pdf

Creswell, J. W., \& Plano Clark., V. L. (2009). Designing and conducting mixed methods research. Sage. Retrieved from https://www.amazon.com/DesigningConducting-Mixed-Methods-Research/dp/1412975174

Creswell, J. W., \& Plano Clark., V. L. (2011). Designing and conducting mixed methods research (2nd ed.). Sage.

Creswell, J. W. (2013). Qualitative inquiry \& research design: Choosing among five approaches (3rd ed.). Sage.

Cyrenne, P., \& Chan, A. (2012). High school grades and university performance: A case study. Economics of Education Review, 31(5), 524-542. https:// doi.org/10.1016/j.econedurev.2012.03.005

Department of Basic Education. (1998). Employment of Educators Act Number 76 of 1998. Government Printers.

Department of Higher Education and Training. (2016). Report from National Council of Provinces as reported by the Department of Higher Education and Training. DHET.

Declercq, K., \& Verboven, F. (2018). Enrollment and degree completion in higher education without admission standards. Economics of Education Review, 66, 223244. https://doi.org/10.1016/j.econedurev.2018.08.008

Farbrother, C., \& Dutton, C. (2005). Responding to change in higher education hospitality provision: Two universities' approaches. Retrieved from http://eprints.bournemouth.ac.uk/12597/1/link12.pdf

Global Human Capital Report. (2014). Skills gap in South Africa's hospitality industry.

Green, F., \& Mason, G. (2015). Skills and training for a more innovation-intensive economy. In D. Bailey, K. Cowling \& P. Tomlinson (Eds.), New perspectives on industrial policy for a modern Britain. Oxford University Press.

Hoare, A., \& Johnston, R. (2010). Widening participation through admissions policy - a British case study of school and university performance. Studies in Higher Education, 36(1), 21-41. https://doi.org/10.1080/03075070903414297

Hospitality Outlook. (2015). The African traveler. Retrieved from https://www.pwc.co.za/en/assets/pdf/hospitality-outlook2015.pdf

Kamau, S. W., \& Waudo, J. (2012). Hospitality industry employers expectation of employees' competencies in Nairobi Hospitals. Journal of Hospitality Management and Tourism, 3(4), 55-63. https://doi.org/10.5897/jhmt.11.022

Kelly, A. V. (2004). The curriculum theory and practices (5th ed.). Sage Publications. 
Kusluvan, S., \& Kusluvan, Z. (2000). Perceptions and attitudes of undergraduate tourism students towards working in the tourism industry in Turkey. Tourism Management, 21(3), 251-270. https://doi.org/10.1016/S0261-5177(99)00057-6

Kraak, A. (2004). Rethinking the high skills thesis in South Africa. In S. McGrath, A. Badroodien, A. Kraak \& L. Unwin (Eds.), Shifting understandings of skills in South Africa: Overcoming the imprint of a low skills regime (pp. 212-238). Retrieved from http://hdl.handle.net/20.500.11910/8071

Lee, C., \& Lee, J. W. (2012). Analysis of the relationships between the hospitality workforce and job-satisfaction factors according to age, gender, native language and racial-ethnicity. Journal of Tourism Hospitality, 1, 104. https://doi.org/10.4172/2167-0269.1000104

Lolli, J. C. (2013). Interpersonal communication skills and the young hospitality leader: Are they prepared? International Journal of Hospitality Management, 32, 295-298. https://doi.org/10.1016/j.ijhm.2012.02.010

McCowan, T. (2017) Higher education, unbundling, and the end of the university as we know it. Oxford Review of Education, 43(6), 733-748. Https://doi.org/10.1080/03054985.2017.13437122017

McGrath, S. (2012). Vocational education and training for development: A policy in need of a theory? International Journal of Educational Development, 32(5), 623-631. https://doi.org/10.1016/j.ijedudev.2011.12.001

McKim, C. A. (2017). The value of mixed methods research. Journal of Mixed Methods Research, 11(2), 202- 222. https:// doi.org/10.1177/1558689815607096

Modor Intelligence. (2019). Hospitality industry in South Africa - growth, trends, and forecasts. Retrieved from https://www.mordorintelligence.com/industryreports/hospitality-industry-in-south-africa

Mourshed, M., Farrell, D., \& Barton, D. (2013). Education to employment: Designing a system that works. McKinsey \& Company. McKinsey Centre for Government. Retrieved from https://www.mckinsey.com/industries/public-and-socialsector/our-insights/education-to-employment-designing-a-system-that-works

Merriam, S. B. (1998). Qualitative research and case study applications in education. JosseyBass.

O'Cathain, A., Murphy, E., \& Nicholl, J. (2010). Three techniques for integrating data in mixed methods studies. https://doi.org/10.1136/bmj.c4587. PMID: 20851841

Patton, M. Q. (2002). Two decades of developments in qualitative inquiry. A personal, experiential perspective. Qualitative Social Work, 1(3), 261-283. https://doi.org/10.1177/1473325002001003636

Pitan, O. S., \& Adedeji, S. O. (2012). Skills mismatch among university graduates in the Nigeria labor market. United States Education Review, 1, 90-98.

Polit, D. F., \& Beck, C. T. (2004). Nursing research: Appraising evidence for nursing practice (7th ed.). Wolters Klower/Lippincott Williams \& Wilkins.

Polit, D. F., \& Hungler, B. P. (1999). Nursing research: Principles and methods (6th ed.). JB Lippincott.

Smith, G., \& Cooper, C. (2000). Competitive approaches to tourism and hospitality curriculum design. Journal of Travel Research, 39(1), 90-95. Retrieved from https://journals.sagepub.com/doi/pdf/10.1177/004728750003900112

Terblanche, T. E. (2017). Technical and Vocational Education and Training (TVET) Colleges in South Africa: A framework for leading curriculum change (Unpublished PhD Thesis, University of Stellenbosch, Stellenbosch).

United Nations Educational, Scientific and Cultural Organisation (UNESCO). 2010. The need to conduct research at TVET colleges. United Nations Educational, Scientific and Cultural Organisation. 
United Nations Educational, Scientific and Cultural Organisation. (UNESCO). 2012. Youth and skills: Putting education to work. United Nations Educational, Scientific and Cultural Organisation.

Whitelaw, P. A., Barron, P. A. \& Buultjens, J. (2009). Training needs of the hospitality industry. CRC for Sustainable Tourism. Retrieved from https://sustain.pata.org/wp-content/uploads/2015/01/80093-Training-NeedsWEB.pdf

Wickham, J., Moriarty, E., Bobek, A., \& Salamonska, J. (2008). Migrant workers and the Irish hospitality sector. Preliminary Report from the Migrant Careers and Aspirations Research Project, Trinity College Dublin.

World Travel and Tourism Council (WTTC). (2019). Global summit. Retrieved from https://www.hospitalitynet.org/event/3004241/wttc-global-summit-2019.html

Yiu, M., \& Law, R. (2012). A review of hospitality internship: Different perspectives of students, employers, and educators. Journal of Teaching in Travel $\mathcal{E}$ Tourism, 12(4), 377-402. https:// doi.org/10.1080/15313220.2012.729459

Zopiatis, A., \& Constanti, P. (2012). Managing hospitality internship practices: A conceptual framework. Journal of Hospitality and Tourism Education, 24(1), 44-51. https://doi.org/10.1080/10963758.2012.10696661 